\title{
Targeting of solid tumors and blood malignancies by antibody-based therapies - EGFR-pathway as an example
}

\author{
Krzysztof Krzemieniecki ${ }^{1}$, Elzbieta Szpyt ${ }^{2}$, Iran Rashedi ${ }^{3,5,6}$, \\ Katarzyna Gawron ${ }^{4}$, Marek Los ${ }^{5,6 *}$ \\ 1 Department of Chemotherapy, \\ M. Sklodowska-Curie Oncology Center, 31-115 Krakow, Poland \\ 2 Bonifratrow Monastyr Hospital, 31-061 Krakow, Poland \\ 3 Department of Medical Genetics, Tehran University of Medical Sciences, \\ 14155-6447 Tehran, Iran \\ 4 Department of General Biology, Silesian Medical School, 41-808 Zabrze, Poland \\ 5 Manitoba Institute of Cell Biology, CancerCare Manitoba, \\ Winnipeg, MB, R3E 0V9, Canada \\ 6 Department of Biochemistry and Medical Genetics, University Manitoba, \\ Winnipeg, $M B$, R3E 3J\%, Canada
}

Received 16 December 2005; accepted 27 March 2006

\begin{abstract}
A well-coordinated interaction between extracellular signals and intracellular response forms the basis of life within multicellular organisms, with growth factors playing a crucial role in these interactions. Discoveries in recent years have shown that components of the Epidermal Growth Factor (EGF) signaling system have frequently been used by cancer cells to autonomously provide survival and proliferation signals. The main focus of this review is the ErbB epidermal growth factor receptor (EGFR) family of receptor tyrosine kinases including ErbB1/EGFR, ErbB2/HER2/neu, ErbB3/HER3, and ErbB4/HER4 as therapeutic targets. Since the ErbB receptor family regulates cell proliferation through the Ras-mitogen-activated protein kinase (RAS/MAPK) pathway, and cell survival and transformation through the phosphatidylinositol 3-kinase (PI3K/AKT) pathway, pharmacological targeting of these pathways is also discussed. We will also address the clinical studies that have been conducted to evaluate antibody-based therapies mostly on solid tumors and hematologic malignancies.
\end{abstract}

(c) Versita Warsaw and Springer-Verlag Berlin Heidelberg. All rights reserved.

Keywords: Ovarex, theragyn, triab, zamyl, zevalin

* E-mail: losmj@cc.umanitoba.ca 


\section{Abbreviations}

\begin{tabular}{|c|c|}
\hline Antibody Dependent Cellular Cytotoxicity & ADCC \\
\hline Antibody-Directed Enzyme Prodrug Therapy & ADEPT \\
\hline Carcino-Embryonal/Antigen & CEA \\
\hline Complement-mediated Cytotoxicity & $\mathrm{CDC}$ \\
\hline Epidermal Growth Factor & EGF \\
\hline Epideremal Growth Factor Receptor & - EGFR \\
\hline Epstein Barr Virus & EBV \\
\hline Food and Drug Administration & FDA \\
\hline Head and Neck Carcinoma & $\mathrm{HNC}$ \\
\hline Hepatocyte Growth Factor Receptor & - HGFR \\
\hline Human Anti-Mouse Antibodies & - HAMA \\
\hline Human T-cell Leukemia Virus & - $\quad$ HTLV \\
\hline Insulin-Like Growth Factor Reeeptor & IGF $\mathrm{R}$ \\
\hline Monoclonal Antibodies & - mAbs \\
\hline Non Small Cell Lung Cancer & NSCLC \\
\hline Phosphatase and Tensin homolog (MMAC1) & PTEN \\
\hline Phosphatidyloinositol 3-Kinase & - $\quad \mathrm{PI} 3 \mathrm{~K} / \mathrm{AKT}$ \\
\hline Platelet Derived Growth Factor & - PDGF \\
\hline Platelet Derived Growth Factor Receptor & PDGF-P \\
\hline Polymorphic Epithelial Mucin & PEM (MÚC1) \\
\hline Polymorphonuclear Leucocytes & $\mathrm{PMN}$ \\
\hline Ras-Mitogen Activated Protein Kinase & RAS/MAPK \\
\hline Single Chain Fv Antibody Fragments & $-\mathrm{scFv}$ \\
\hline Single Nucleotide Polymorphism & SNP \\
\hline Transforming Growth Factor Receptor & TGFR \\
\hline Tumor Associated Antigen & TAA \\
\hline Tumor Specific Antigen & TSA \\
\hline Vascular Endothelial Growth Factor & VEGF \\
\hline Vascular Endothelial Growth Factor Receptor & VEGF $\mathrm{P}_{\lambda}$ \\
\hline
\end{tabular}

\section{Introduction}

Programmed cell death, or apoptosis, is crucial for the development, homeostasis, and regeneration processes during the lifetime of multicellular organisms [1-4]. This so called "death per default" can be activated both by the self-activation of death receptors (autocrine suicide), or by the activation of the mitochondrial/apoptosome-dependent/intrinsic death pathway [5-7]. Active death signals may not be the only stimuli inducing apoptotic cell death, as apoptosis may also be a consequence of the lack of pro-survival signals mediating through cell surface receptors. Several strategies have been developed to explore the mechanisms of inhibiting cell growth and survival signaling pathways. For example, peptides derived from "interaction surfaces" between critical molecules within death signaling and other pathways competitively inhibit these signals [8-10]. In addition to these peptides, so called peptidomimetics which are non-peptide molecules that share structural similarities with blocking peptides, are subjects of interest for the pharmacological industry because they are often more stable and also exhibit other favorable properties such as improved cell membrane permeability.

Dysregulation of protein components of diverse growth factors-activated signaling 
pathways, or alterations in the receptor-kinases themselves are frequently found in various cancers. Furthermore, the pleiotropic functions of mutated growth factor receptors contribute to drug resistance by blocking apoptotic signaling pathways. Therefore, growth factors and their receptors, as well as other components involved in signaling cascades, are frequent targets for combined cancer therapies [11]. The inappropriate expression of growth factors or their receptors resulting in uncontrolled cell growth and suppression of apoptosis [4, 12] may effectively be blocked by antibodies [13].

Antibodies may be used in many different ways against cancer and other diseases. For example, antibodies may target specific components of tumor development such as angiogenesis growth factor receptors (e.g. EGFR), thus interfering with ligand-receptor interactions, or directly kill tumor cells through activation of death receptor-mediated pathways [13-15]. Additionally, antibodies can invoke an immune response by inducing complement-mediated cytotoxicity (CDC) or antibody-dependent cellular cytotoxicity (ADCC).

\section{A synopsis of antibody-based therapies and current development}

Attempts to use antibodies against cancer began in the 1950's and relied on polyclonal antibody preparations. The technology however gained feasibility in 1975 when Kohler and Milstein developed techniques for the production of monoclonal antibodies (mAb, identical antibodies directed against specific antigens) [16]. Initially, murine, rabbit and rat antibodies were studied; however, they had several associated problems since they acted as immunogens themselves which were recognized as foreign antigens by the host immune system resulting in generating a humoral response against the therapeutic antibodies. The resulting immune response would then cause occasional, adverse effects such as "serum-sickness" and anaphylaxis. In addition, due to cross-species incompatibilities these antibodies were sometimes unable to stimulate cytotoxic humoral or cellular immune responses such as CDC and ADCC, which are necessary to destroy malignant cells. In order to overcome this problem, chimeric or "hybrid antibodies" were constructed by linking human antibody backbone regions with murine or primate variable regions. More advanced versions of these antibodies were subsequently developed that are known as "humanized antibodies" today (human Ig framework containing only rodent sequences encoding the three complementarity determining regions). These antibodies have shown increased activities to trigger immune responses (both CDC and ADCC) in clinical trials $[17]$.

Since then attempts have been made to further improve the cytotoxic activity of therapeutic monoclonal antibodies. For example, conjugation of therapeutic monoclonal antibodies with $\beta$-glucan markedly enhances the recruitment of complement-lytic cascade components, thereby improves their CDC or ADCC activities. For instance, Herceptin (trastuzumab), Rituxan/Mabthera (rituximab) and Erbitux (cetuximab) (Table 1) promote tumor regression by enhancing the leukocyte-mediated killing of tumor cells coated 
with the iC3b-receptor in which $\beta$-glucan acts via the iC3b-receptor (found on tumor cells) and complement receptor 3 (found on leukocytes). Combinations of mAb and $\beta$-glucan have also been shown to significantly increase tumor regression in breast and liver tumor models [18].

\section{Examples of conjugated (armed) antibodies}

Single chain Fv antibody fragments (scFvs) can be engineered to form dimers and trimers by varying the length of their polypeptide linkers. A scFv fragment with a linker length of 3-12 residues cannot fold into a functional Fv domain, and therefore associates with another scFv molecule to form a bivalent dimer. Trimers and tetramers can be formed by further reducing the length of this linker. These molecules have the advantage of increased tumor penetration and faster clearance rates than the parental Ig due to their smaller size. Designing therapeutic antibodies to include the Fc domain prolongs their serum half-life and complement-mediated effects. In addition, antibody fragments can be fused with a wide variety of molecules to gain new functions and altered activities including radioisotopes for cancer imaging, enzymes for prodrug therapy, or lipids for improved systemic delivery [19].

Bispecific diabodies (also called bispecific antibodies) are formed through the association of two different scFv molecules that each contains a VH and VL domain (variable regions from both heavy and light chain) from a different parental Ig (Fig. 1). These bispecific antibodies usually recognize two different antigens, hence are able to crosslink different target antigens either on the same cell or on two different cells. As a result, they may efficiently recruit cytotoxic $T$ cells to target cancer cells or effectively activate CDC.

The direct arming of antibodies is a strategy used to enhance the effectiveness of anti-tumor antibodies (Table 1). This is accomplished by covalently linking antibodies to molecules or proteins that are used to destroy tumor cells such as radionuclides, toxins or cytokines. The latter stimulates the anti-tumor immune response without the toxicity associated with systemic cytokine delivery. Antibodies can also be armed indirectly by attaching engineered antibody fragments to the surface of liposomes loaded with drugs or toxins for tumor-specific delivery [20]. For example, in preclinical studies anti-HER2 scFv immunoliposomes containing doxorubicin showed increased retention in circulation, and improved efficiency compared to free doxorubicin, non-antibody conjugated liposomal doxorubicin, and the anti-HER2 monoclonal antibody trastuzumab [21]. Another example in this context is Mylotarg (gemtuzumab ozogamicin), a humanized anti-CD33 monoclonal antibody which is covalently linked to the cytotoxin calicheamicin. CD33 is expressed on early myeloid cells, as well as leukemic blast cells, but is rarely expressed outside the hematopoietic system, making it an attractive therapeutic target. Mylotarg binding to CD33 leads to endocytosis, followed by cleavage of the covalent linkage between the antibody and calicheamicin inside the lysosome. The calicheamicin is released and then induces sequence specific cleavage of double-stranded DNA [22].

Antibodies may also be labeled with a radionuclide either for diagnostic or for thera- 


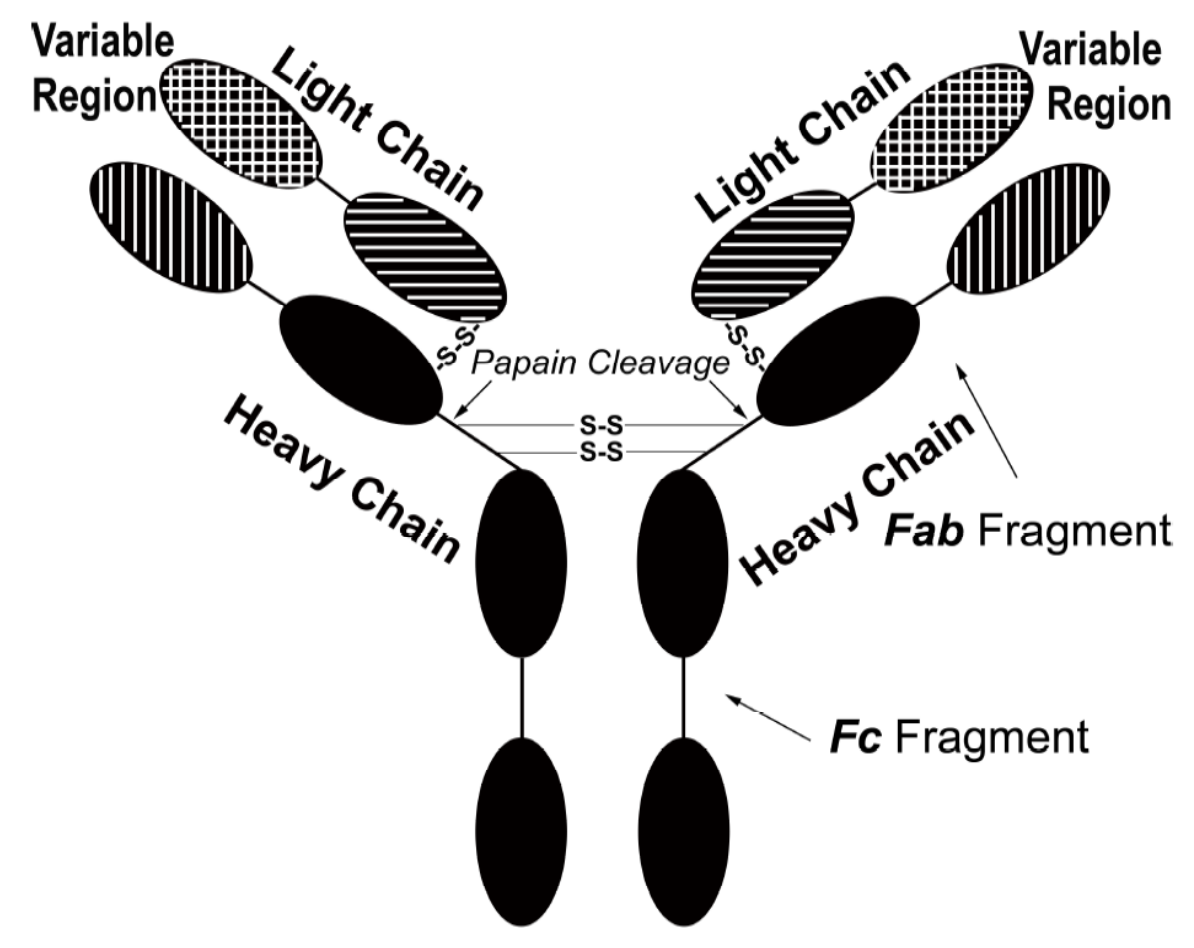

Fc - constant part of the antibody (typical for the particular class of an antibody). Fabfragment of an antibody that contains their variable (antigen recognizing) regions. Fabs can be obtained by the treatment of whole antibodies with endoprotease papain.

Fig. 1 Structure and key components of an antibody (IgG).

peutic purposes. Thus the antibodies may serve as vectors targeting tumor antigens; for example radioactive anti-carcinoembryonic antigen antibodies are used in the treatment of colorectal cancer. This strategy works through the accumulation of high-energy $\beta$-particles (with a short penetration depth) emitted from a radionuclide $\left({ }^{131} \mathrm{I},{ }^{90} \mathrm{Yt},{ }^{111} \mathrm{In}\right)$ within the tumor. Using this method in conjunction with a gamma-detector also makes it possible to locate and stage tumors [23]. Recently, two radioimmunoconjugates, Zevalin and Bexxar, were approved for treating non-Hodgkin's lymphoma. Zevalin (Ibritumomab Tiuxetan) is a ${ }^{90} \mathrm{Yt}$ labeled anti-CD20 monoclonal antibody that incorporates $\beta$-emitting radioisotopes [24], while Bexxar (Tositumomab) has the same antigen specificity but is conjugated to ${ }^{131} \mathrm{I}[25,26]$.

Antibody-Directed Enzyme Prodrug Therapy (ADEPT), a strategy that employs enzyme immunoconjugates to locally activate prodrugs, uses antigens that are present on tumor cells to direct enzymes to the tumor site. After the enzyme-antibody conjugate has been delivered, and has had sufficient time to bind target cells and be cleared from the system, a prodrug is administered and activated extracellularly at the tumor site [27]. The Rituximab-alliinase->alliin->allicin therapeutic system provides one such example of this strategy. Rituximab is a chimeric mouse/human monoclonal antibody designed to treat non-Hodgkin's lymphoma. It recognizes the CD20 antigen which is expressed on malignant and normal B cells, but is not found on other tissues [28]. The effectiveness of Rituximab is enhanced by being covalently linked (armed) with the enzyme alliinase. 
The alliinase-Rituximab complex specifically binds lymphoma and B cells, penetrates and kills tumor cells following the injection of alliin (found in plants such as garlic and onion) which is converted by the alliinase to allicin [29].

\begin{tabular}{|c|c|c|}
\hline Name/Industry Code & Target/Mode of Action & Company \\
\hline $\begin{array}{l}\text { ABX-EGF } \\
\text { (Panitumumab) }\end{array}$ & $\begin{array}{l}\text { Monoclonal antibody that blocks the action of epidermal } \\
\text { growth factor receptor Erb1/EGFR }\end{array}$ & Abenix \\
\hline $\begin{array}{l}\text { Avastin } \\
\text { (Bevacizumab) }\end{array}$ & Angiogeneis inhibitor. Targets VEGF & $\begin{array}{l}\text { Genentech } \\
\text { BioOncology }\end{array}$ \\
\hline $\begin{array}{l}\text { BEC2 } \\
\text { (Mitumomab) }\end{array}$ & $\begin{array}{l}\text { Vaccine mimicking GD3 glycopeptide (Anti-idiotypic } \\
\text { mAb, mimicking GD3 ganglioside) }\end{array}$ & $\begin{array}{l}\text { ImClone Systems, Merck } \\
\text { KGaA }\end{array}$ \\
\hline $\begin{array}{l}\text { Bexxar } \\
\text { (Tositumomab) }\end{array}$ & $\begin{array}{l}{ }^{131} \text { I conjugate targets CD20 on B-cells (mainly non- } \\
\text { Hodgkin lymphoma treatment) }\end{array}$ & $\begin{array}{l}\text { Corixa, GlaxoSmith- } \\
\text { Kline, Titan Pharm. }\end{array}$ \\
\hline $\begin{array}{l}\text { Campath } \\
\text { (Alemtuzumab) }\end{array}$ & $\begin{array}{l}\text { Binds CD52 and triggers antibody-mediated lysis of B } \\
\text { cells }\end{array}$ & $\begin{array}{l}\text { BTG, ILEX Oncology, } \\
\text { Hoffman-LaRoche, } \\
\text { Millennium }\end{array}$ \\
\hline CeaVac & $\begin{array}{l}\text { Stimulates immune response to CEA (Anti-iodiotypic } \\
\text { mAb, mimicking CEA) }\end{array}$ & Titan Pharmaceuticals \\
\hline $\begin{array}{l}\text { EMD } 72000 \\
\text { (Mastuzimab) }\end{array}$ & $\begin{array}{l}\text { Monoclonal antibody that blocks the action of epidermal } \\
\text { growth factor receptor Erb1/EGFR }\end{array}$ & Merck KgaA \\
\hline $\begin{array}{l}\text { Erbitux } \\
\text { (Cetuximab, for- } \\
\text { merly: IMC-C225) }\end{array}$ & $\begin{array}{l}\text { Monoclonal antibody that blocks the action of epidermal } \\
\text { growth factor receptors }\end{array}$ & $\begin{array}{l}\text { ImClone Systems, Merck } \\
\text { KgaA }\end{array}$ \\
\hline $\begin{array}{l}\text { Herceptin } \\
\text { (Trastuzumab) }\end{array}$ & Blocks EGF by attaching to ErbB2/HER2/neu & Genentech \\
\hline $\begin{array}{l}\text { Lymphocide } \\
\text { (Epratuzumab) }\end{array}$ & $\begin{array}{l}\text { Binds to the extracellular domain of CD } 22 \text { and induces } \\
\text { its internationalization and phosphorylation }\end{array}$ & Immunomedics \\
\hline MDX-210 & $\begin{array}{l}\text { Bispecific Ab that directs immune response against cells } \\
\text { overexpressing ErbB2 by crosslinking ErbB2/HER2/neu } \\
\text { with CD64 (Fc } \gamma \mathrm{RI})\end{array}$ & $\begin{array}{l}\text { Medarex, Immuno } \\
\text { Designed Molecules }\end{array}$ \\
\hline $\begin{array}{l}\text { Mylotarg } \\
\text { (Gemtuzumab } \\
\text { ozogamicin) }\end{array}$ & $\begin{array}{l}\text { Chemoimmunotherapeutic agent targeting CD33 on } \\
\text { leukemic cells }\end{array}$ & $\begin{array}{l}\text { Wyeth Laboratories/ } \\
\text { AHP }\end{array}$ \\
\hline Ovarex & $\begin{array}{l}\text { Monoclonal antibody. Binds to CA } 125 \text {, a tumor associ- } \\
\text { ated antigen, in the majority of ovarian cancers. Induces } \\
\text { an immune response against CA } 125\end{array}$ & Altarex \\
\hline $\begin{array}{l}\text { Panorex } \\
\text { (Edrecolomab) }\end{array}$ & $\begin{array}{l}\text { Murine mAb targeting the epithelial cell adhesion } \\
\text { molecule EpCam }\end{array}$ & $\begin{array}{l}\text { GlaxoSmith-Kline, } \\
\text { Centocor }\end{array}$ \\
\hline $\begin{array}{l}\text { Rituxan/Mabthera } \\
\text { (Rituximab) }\end{array}$ & $\begin{array}{l}\text { Lyses B lymphocytes through activation of CDC and } \\
\text { ADCC upon targeting of CD } 20\end{array}$ & $\begin{array}{l}\text { IDEC Pharmaceuticals, } \\
\text { Genentech }\end{array}$ \\
\hline $\begin{array}{l}\text { Theragyn } \\
\text { (Pemtumomab) }\end{array}$ & Activates ADCC by targeting PEM (MUC1) & Antisoma \\
\hline TriAb & $\begin{array}{l}\text { Anti-idiotype antibody targeting ovarian cancer. Mimics } \\
\text { the HMFG antigen triggering immune response }\end{array}$ & Titan Pharmaceuticals \\
\hline Zamyl & Binds CD33 to induce immune response & Protein Design Labs \\
\hline $\begin{array}{l}\text { Zevalin } \\
\text { (Ibritumomab Titux- } \\
\text { etan) }\end{array}$ & $\begin{array}{l}\text { Radioimmunotherapy targeting CD20 using }{ }^{90} \text { Yt-labeled } \\
\text { antibody }\end{array}$ & IDEC Pharmaceuticals \\
\hline
\end{tabular}

Table 1 Examples of clinical and experimental antibody-based compounds. 


\section{Examples of tumor-associated antigens as desired targets for antibody therapy}

Mutations which occur mainly within the components of stimulatory pathways, DNA damage control machinery, cell cycle progression or within genes that control programmed cell death, underlie oncogenic transformation $[3,11,30]$. The acquisition of a malignant phenotype is often accompanied by a change in antigenicity due to the expression of "tumor-specific antigens" (TSA) [31]. Furthermore, genetic instability frequently occurs in cancers that acquire mutations within the myc proto-oncogene, or in the genes encoding proteins that guard cell cycle check-points, which thus contributes to the creation of new fusion proteins with antigenic properties [30]. These changes form the basis for modern mAb-based therapies. More commonly, tumors express "tumor-associated antigens" (TAA) which are present on tumor cells and on normal cells during fetal development [31]. Also, the ethiology of some cancers may be related to viral infections; for example 'hairy' T-cell leukemia is caused by the Human T-cell Leukemia Virus (HTLV) [32], certain non-Hodgkin B-cell lymphomas are caused by the Epstein-Barr Virus (EBV), and cervical cancer may be caused by certain strains of the Papilloma Virus. However, it is most likely that viral infection only makes cells more prone to cancer (by assisting malignant transformation) rather than being the sole causative agent. Such malignancies may occasionally express "viral antigens", proteins completely foreign to our cells, encoded by viral genetic material [33].

\section{Targeting of growth-factor receptors by monoclonal antibodies}

MAbs can block growth factor receptors overexpressed on cancer cells; including EGFR, TGF $\alpha$ R, VEGF-R, IGF-1R, HGFR, Brc-Ab1 kinase, PDGF-R, and c-kit [34-38]. Cancer cells devoid of proper growth and/or survival signals either die, or became more sensitive to conventional chemo- or radiotherapy. Antibodies are also tested for being used in targeting tumor angiogenesis. Thus, besides VEGF, other targets for monoclonal antibody-based anti-angiogenetic therapies include the basic fibroblast growth factor, several other growth factor receptors and a number of cell adhesion molecules [39]. To date, 17 antibodies have been approved by FDA, eight of them are used to combat malignant diseases (Table 1) [39]. Below, we discuss in more detail some of the recent advances in antibody-based cancer therapies.

\section{Therapeutic inhibition of receptor-tyrosine kinases that propagate growth or survival signals}

One of the fastest and most efficient ways for a cell to receive signals, both generated by cell-cell interaction and by humoral messengers, is via cell surface receptors coupled with kinases known as receptor tyrosine kinases. All 16 structural tyrosine kinase sub- 
families, each dedicated to its complementary family of protein ligands, function in the same way. The binding of a signaling protein to the ligand-binding domain in the extracellular part triggers receptor dimerization or oligomerization which in turn causes an intracellular rearrangement of the kinase domain and its consequent activation. The neighboring activated kinase domains cross-phosphorylate each other at multiple tyrosine residues (autophosphorylation), and then activate other proteins by transferring a phosphate group from ATP to their phosphoreceptor sites. Most of the proteins activated by the receptor tyrosine kinases are also kinases themselves whose activation leads to an expanding cascade of phosphorylation within the cytosol leading either directly to the phosphorylation of transcription factors and subsequent activation of cell growth, proliferation, differentiation and cell survival, or indirectly to activation of a second messenger which mediates the cell's behavior.

The most frequently dysregulated receptor tyrosine kinases in human cancers are members of the epidermal growth factor ErbB receptor family (ErbB1/EGFR, ErbB2/ HER2/neu, ErbB3/HER3, and ErbB4/HER4), which regulate cell proliferation through the Ras-mitogen-activated protein kinase (RAS/MAPK) pathway and cell survival and transformation through the phosphatidylinositol 3-kinase (PI3K/AKT) pathway [40]. Interestingly, PTEN, the phosphatase that negatively regulates the PI3K/AKT-pathway, is also frequently mutated in metastatic cancers [41, 42]. Among the four HER family receptors, most attention has been given to ErbB1/EGFR and ErbB2/HER2/neu [10, 11] discussed below.

\section{ErbB2/HER2/neu; an effective therapy target for solid tumors and hematologic malignancies}

The ErbB2/HER2/neu pathway gained a lot of attention as a possible therapeutic target when mAb mumAb4D5 was shown to be capable of recognizing the extracellular domain of HER2/neu and inhibiting the growth of breast cancer cell lines via ADCC [43]. mAb mumAb4D5's recognition of the desired domain was accomplished by immunization with the NIH 3T3 line that overexpresses the HER2 [43]. In 1992, Carter et al. created a recombinant humanized version of mumAb4D5, called rhumAb4D5, to eliminate the risk of immunological consequences of mouse antibodies administered to humans [44]. rhumAb4D5 possesses a three-fold higher affinity for ErbB2/HER2/neu and also mediates ADCC in breast tumor lines. The rhumAb4D5, named trastuzumab or Herceptin, became the first clinically approved mAb-based drug that targets an oncogene product. Trastuzumab also increases the amount of hypoxia-induced cell death in breast cancer cells by blocking the pro-survival signals delivered by EGFR1. Experimental evidence further indicates that trastuzumab enhances the responsiveness of ErbB2-overexpressing breast cancer cells to taxanes, anthracyclines, and platinum compounds (cisplatin, vinorelbine/navelbine, doxorubicin, paclitaxel) [45]. Treatment with trastuzumab is well tolerated, with low-grade fever, chills, and fatigue observed frequently, but mostly only after the first administration. A combinatorial treatment of trastuzumab with doxorubicin 
or paclitaxel, nevertheless, causes increased cardiotoxicity, via an unknown mechanism, and marked lung metastases.

\section{Therapeutic targeting of ErbB1/EGFR in recent clinical tri- als}

The ErbB1/EGFR signaling pathway has recently been successfully targeted by cetuximab, a humanized mAb, which is marketed under the name Erbitux. Erbitux has been tested for the treatment of a variety of aggressive cancers, including HNC, colorectal, NSCLC and pancreatic cancer. In all cancers, Cetuximab successfully increased the average survival rate of patients and stabilized the progression of the disease when combined with other drugs. In HNC, Cetuximab has also been tested in combination with chemotherapy and radiotherapy [46]. A combination of Cetuximab with cis/carboplatin and 5-fluorouracil was tested by Cunningham et al. (2004) and showed an increased disease control rate. In colorectal cancer, the combination of Cetuximab and irinotecan significantly increased the response rate, and stalled the progression of the disease [47]. In NSCLC, a combined treatment of Cetuximab with paclitaxel and carboplatin, or gemcitabine and carboplatin, led to an increased survival rate. The same results were obtained by combining Cetuximab and docetaxel to obtain a $66 \%$ rate of stable disease. A phase II trial of Cetuximab and gemcitabine has recently been published for treatment of pancreatic cancer [48] and demonstrated the same increased rates of one-year progression-free survival and overall survival. Mucositis, which is the most common radiation-related side effect was not enhanced by concomitant Cetuximab therapy [49].

Phase II studies focusing on Panitumumab (ABX-EGF), which binds EGFR with high affinity, revealed promising results, showing the stabilization of disease progression, and dose dependent skin toxicity as the only major side effect [50]. Matuzumab (EMD 72000), which is another humanized antibody that binds to EGFR receptors, has also recently entered clinical trials $\mathrm{s}_{\boldsymbol{N}}$ A phase I study of combinatorial treatment with Matuzumab and gemcitabine in advanced pancreatic cancer has shown a stabilization of disease progression in 12 of 17 patients $[?$, new

A new strategy targeting the EGFR pathway is a combination treatment of mAbs and tyrosine kinase inhibitors. An increased inhibition of EGFR-dependent signaling, and therefore an induction of apoptosis, could be achieved by combinatorial therapy with gefitinib $[5]_{\lambda}$ or erlotinib [52] and Cetuximab. In addition, the concomitant use of two mAbs (two-antibody therapy) might be a promising strategy towards the inhibition of tumor growth, and averting of the progression of disease. mAbs either targeting different parts of the same receptor, or different ErbB receptors, may result in interference in the formation (dimerization) of active signaling complexes. 


\section{Vascular endothelial growth factor (VEGF) and its receptor as therapeutic targets}

VEGF is a member of PDGF family which stimulates angiogenesis and lymphangiogenesis, and increases the permeability of vascular endothelium. VEGF receptors are highly expressed in vascular endothelial cells and play an important role in the regulation processes of physiological and pathological growth and development, and in the maintenance of blood and lymphatic vessels. Overexpression of VEGF has been found in various tumor samples and correlates with high expression of VEGF receptors, which in turn leads to an increase in tumor proliferation and poor survival. Bevacizumab (Avastin) is a humanized $\mathrm{mAb}$ against VEGF which inhibits VEGF-induced uncontrolled angiogenesis and lymphangiogenesis, and therefore tumor formation and growth. Hurwitz et al. showed an increase in median survival, progression free survival, response rate and duration of response in a phase III trial with colorectal cancer patients $[53]$. The observed toxicity, which was mainly in the form of hypertension, was low, but more severe side effects like drug administration-related bleeding to the central nervous system and perforations within the alimentary tract have sporadically been reported. Furthermore, renal cancer represents a suitable target for Bevacizumab because the major etiologic event in this cancer is an upregulation of VEGF, induced by a biallelic loss of the von Hippel-Lindau tumor suppressor gene. In contrast, no significant differences in a phase III study with metastatic breast cancer patients could be seen. The use of Bevacizumab in combination with gemcitabine for pancreatic cancer is currently under investigation. In HNC, angiogenesis has been linked with tumor progression, which is why a combinatorial treatment with $\mathrm{mAb}$ and tyrosine kinase inhibitors might be a successful approach in this case. Current studies evaluating a combinational treatment with Bevacizumab and erlotinib [54 $\bigwedge_{\lambda}$ demonstrate an increase in disease stabilization. Bevacizumab and erlotinib are also being tested in NSCLC $[55]$ in metastatic renal cancer and breast cancer.

\section{Epilogue}

As shown by the above examples, TAA-directed antibodies are increasingly being used in clinical settings. As mutation mapping, SNP mapping and other genome-wide screening approaches become more popular [56] it is predictable that in parallel to identifying more TAAs, the monoclonal antibody-based treatment of cancer and also autoimmune diseases will become more common. Although monoclonal antibodies are considered to be potential "magic bullets" for cancer and other disease treatments, there are certain problems that limit their application and need to be solved. Various factors are responsible for the low efficacy of antibodies. First, incomplete antibodies like those discussed in the first section of this review have short in vivo half-lives and do not kill cells with great efficiency, and furthermore they do not always fix human complement or elicit ADCC with human mononuclear cells. Also, in many cases they are not directed against growth receptors that are essential for cell survival and proliferation $[57]$. Conjugated antibodies 
in which drugs, toxins or radionuclides are attached to naked monoclonal antibodies have been constructed, but only a few of them are currently used for therapy due to multiple side effects. The side effects are typically results of the substances that are attached to a particular antibody. Above all, unless so called 'humanized antibodies' are developed there are immunogenity problems irrespective of whether the antibody is naked or conjugated. Monoclonal antibodies produced in mice trigger an immune response when injected into humans producing HAMA (human anti-mouse antibodies). This results in the elimination of therapeutic antibodies from the host and also causes the formation of immune complexes that can result in damage to the kidneys. Monoclonal antibodies raised in humans would lessen this problem, but most attempts made so far have been unsuccessful. This problem has been reduced, to some extent, by the use of genetic engineering to produce mouse-human hybrid antibodies (e.g. Infliximab, Rituximab, Vitaxin etc.)

Human $\operatorname{Ig}_{1}$ is the most widely used chimeric monoclonal antibody for tumor therapy as it effectively triggers ADCC by mononuclear effector cells, activates human complement $[58]$ and has an extended plasma life $[59]_{\hat{\kappa}}$ However, human $\operatorname{IgG}_{1}$ also binds to Fc receptors on non-cytotoxic cells such as Fc $\gamma$ RII on platelets and B cells, Fc $\gamma$ RIIIb on PMNs, and Fc receptors which even inhibit effector cell activation (such as Fc $\gamma$ RIIb on monocytes/macrophages). This interaction with the inhibitory Fc $\gamma$ RII isoform was demonstrated to diminish Herceptin's activity in animal models $[60]_{\mathcal{K}}$ To overcome the difficulties associated with monoclonal antibodies, bispecific antibodies have been proposed. In vitro studies have shown that chemically-linked bispecific antibodies directed against the $\mathrm{Fc} \gamma, \mathrm{Fc} \gamma \mathrm{RIII}(\mathrm{CD} 16), \mathrm{Fc} \gamma \mathrm{RI}(\mathrm{CD} 64)$, and the $\mathrm{Fc} \alpha \mathrm{RI}(\mathrm{CD} 89)$ receptors were more effective than conventional antibodies. Animal studies have also confirmed the efficacy of these molecules, but results from clinical trials have been less promising because of their short plasma half-lives comparing to conventional antibodies.

Furthermore, antibody structure also has a profound effect on tumor targeting. IgG, a large protein of approximately $150 \mathrm{kDa}$ in mass, has slower kinetics in distribution and severely limits tissue penetration comparing to small molecules. Thus, alteration of antibody structure can improve quantitative and selective tumor targeting [61] $]_{\kappa}$ In spite of the potential difficulties mentioned above, at least 17 monoclonal antibodies have been approved by FDA, while many more are still in clinical trials. Moreover, some of these antibodies are also used effectively in combination with chemotherapy. It is expected that as we learn how to improve the pharmacokinetic properties of antibodies, and diminish their adverse interactions with the immune system, monoclonal antibodies will gain importance as therapeutic molecules, either alone or in combination with the "classical" cancer radio- and chemotherapy.

\section{Acknowledgment}

M.L. thankfully acknowledges support by the CFI-Canada Research Chair, PCRFC-, CCMF-, CIHR-RPP-, MICH- and MMSF-financed programs. 


\section{References}

[1] M.C. Raff: "Social controls on cell survival and cell death", Nature, Vol. 356, (1992), pp. 397-400.

[2] D.G. Stupack and D.A. Cheresh: "Get a ligand, get a life: integrins, signaling and cell survival", J. Cell Sci., Vol. 115, (2002), pp. 3729-3738.

[3] A. Philchenkov, M. Zavelevich, T.J. Kroczak and M. Los: "Caspases and cancer: mechanisms of inactivation and new treatment modalities", Exp. Oncol., Vol. 26, (2004), pp. 82-97.

[4] M. Kreuter, C. Langer, C. Kerkhoff, P. Reddanna, A.L. Kania, S. Maddika, K. Chlichlia, T.N. Bui and M. Los: "Stroke, myocardial infarction, acute and chronic inflammatory diseases: caspases and other apoptotic molecules as targets for drug development", Arch. Immunol. Ther. Exp., Vol. 52, (2004), pp. 141-155.

[5] M. Los, S. Wesselborg and K. Schulze Osthoff: "The role of caspases in development, immunity, and apoptotic signal transduction: lessons from knockout mice", Immunity, Vol. 10, (1999), pp. 629-639.

[6] M. Hashemi, F. Karami-Tehrani, S. Ghavami, S. Maddika and M. Los: "Adenosine and deoxyadenosine induces apoptosis in estrogen receptor positive and negative human breast cancer cells via the intrinsic pathway", Cell Proliferat., Vol. 38, (2005), pp. 269-285.

[7] M. Loeffler and G. Kroemer: "The mitochondrion in cell death control: certainties and incognita", Exp. Cell Res., Vol. 256, (2000), pp. 19-26.

[8] A.F. Kabore, J.B. Johnston and S.B. Gibson: "Changes in the apoptotic and survival signaling in cancer cells and their potential therapeutic implications", Curr. Cancer Drug Targets, Vol. 4, (2004), pp. 147-163.

[9] K. Hauff, C. Zamzow, W.J. Law, J. de Melo, K. Kennedy and M. Los: "Peptide-based approaches to treat asthma, arthritis, other autoimmune diseases and pathologies of the central nervous system", Arch. Immunol. Ther. Exp., Vol. 53, (2005), pp. 308320.

[10] F.J. Mendoza, P.S. Espino, K.L. Cann, N. Bristow, K. McCrea and M. Los: "Antitumor chemotherapy utilizing peptide-based approaches-apoptotic pathways, kinases, and proteasome as targets", Arch. Immunol. Ther. Exp., Vol. 53, (2005), pp. $47-60$.

[11] J.G. Brown and S.B. Gibson: "Growth Factors, Receptors, and Kinases: their Exploration to Target Cancer", In: M. Los and S.B. Gibson (Eds.): Apoptotic pathways as target for novel therapies in cancer and other diseases, Springer, 2005, pp. 173-196.

[12] S. Kitada, J. Andersen, S. Akar, J.M. Zapata, S. Takayama, S. Krajewski, H.G. Wang, X. Zhang, F. Bullrich, C.M. Croce, K. Rai, J. Hines and J.C. Reed: "Expression of apoptosis-regulating proteins in chronic lymphocytic leukemia: correlations with In vitro and In vivo chemoresponses", Blood, Vol. 91, (1998), pp. 3379-3389.

[13] E.P. Booy, D. Johar, S. Maddika, H. Pirzada, M.M. Sahib, I. Gehrke, S.D. Loewen, S.D. Louis, K. Kadkhoda, M. Mowat and M. Los: "Monoclonal and Bispecific An- 
tibodies as Novel Therapeutics", Arch. Immunol. Ther. Exp., Vol. 54, (2006), pp. $1-17$.

[14] M. Los, M. van de Craen, C.L. Penning, H. Schenk, M. Westendorp, P.A. Baeuerle, W. Dröge, P.H. Krammer, W. Fiers and K. Schulze-Osthoff: "Requirement of an ICE/Ced-3 protease for Fas/Apo-1-1mediated apoptosis", Nature, Vol. 371, (1995), pp. $81-83$.

[15] B.C. Trauth, C. Klas, A.M. Peters, S. Matzku, P. Moller, W. Falk, K.M. Debatin and P.H. Krammer: "Monoclonal antibody-mediated tumor regression by induction of apoptosis", Science, Vol. 245, (1989), pp. 301-305.

[16] G. Kohler and C. Milstein: "Continuous cultures of fused cells secreting antibody of predefined specificity", Nature, Vol. 256, (1975), pp. 495-497.

[17] C.A. White, R.L. Weaver and A.J. Grillo-Lopez: "Antibody-targeted immunotherapy for treatment of malignancy", Annu. Rev. Med., Vol. 52, (2001), pp. 125-145.

[18] F. Hong, R.D. Hansen, J. Yan, D.J. Allendorf, J.T. Baran, G.R. Ostroff and G.D. Ross: "Beta-glucan functions as an adjuvant for monoclonal antibody immunotherapy by recruiting tumoricidal granulocytes as killer cells", Cancer Res., Vol. 63, (2003), pp. 9023-9031.

[19] A.A. Kortt, O. Dolezal, B.E. Power and P.J. Hudson: "Dimeric and trimeric antibodies: high avidity scFvs for cancer targeting", Biomol. Eng., Vol. 18, (2001), pp. 95-108.

[20] P. Carter: "Improving the efficacy of antibody-based cancer therapies", Nat. Rev. Cancer, Vol. 1, (2001), pp. 118-129.

[21] J.W. Park, K. Hong, D.B. Kirpotin, G. Colbern, R. Shalaby, J. Baselga, Y. Shao, U.B. Nielsen, J.D. Marks, D. Moore, D. Papahadjopoulos and C.C. Benz: "AntiHER2 immunoliposomes: enhanced efficacy attributable to targeted delivery", Clin. Cancer Res., Vol. 8, (2002), pp. 1172-1181.

[22] F. Giles, E. Estey and S. O'Brien: "Gemtuzumab ozogamicin in the treatment of acute myeloid leukemia", Cancer, Vol. 98, (2003), pp. 2095-2104.

[23] Y. Yovtchev and S. Nilolov: "Opportunities for up to date treatment of the colorectal cancer", Radiol. Oncol., Vol. 35, (2001), pp. 111-115.

[24] M.K. Robinson, L.M. Weiner and G.P. Adams: "Improving Monoclonal Antibodies for Cancer Therapy", Drug Dev. Res., Vol. 61, (2004), pp. 172-187.

[25] P. Houshmand and A. Zlotnik: "Targeting tumor cells", Curr. Opin. Cell Biol., Vol. 15, (2003), pp. 640-644.

[26] M.C. Hernandez and S.J. Knox: "Radiobiology of radioimmunotherapy: targeting CD20 B-cell antigen in non-Hodgkin's lymphoma", Int. J. Radiat. Oncol. Biol. Phys., Vol. 59, (2004), pp. 1274-1287.

[27] M. Rooseboom, J.N. Commandeur and N.P. Vermeulen: "Enzyme-catalyzed activation of anticancer prodrugs", Pharmacol. Rev., Vol. 56, (2004), pp. 53-102.

[28] A.J. Grillo-Lopez, C.A. White, B.K. Dallaire, C.L. Varns, C.D. Shen, A. Wei, J.E. Leonard, A. McClure, R. Weaver, S. Cairelli and J. Rosenberg: "Rituximab: the first monoclonal antibody approved for the treatment of lymphoma", Curr. Pharm. 
Biotechnol., Vol. 1, (2000), pp. 1-9.

[29] F.D. Arditti, A. Rabinkov, T. Miron, Y. Reisner, A. Berrebi, M. Wilchek and D. Mirelman: "Apoptotic killing of B-chronic lymphocytic leukemia tumor cells by allicin generated in situ using a rituximab-alliinase conjugate", Mol. Cancer Ther., Vol. 4, (2005), pp. 325-331.

[30] S. Panigrahi and S. Mai: "Telomeres, genomic instability, DNA repair and Breast Cancer", Curr. Med. Chem. Anti-Inflamm \& Anti-Allg Agents, Vol. 4, (2005), pp. 421-428.

[31] M. Whelan, J. Whelan, N. Russell and A. Dalgleish: "Cancer immunotherapy: an embarrassment of riches?", Drug Discov. Today, Vol. 8, (2003), pp. 253-258.

[32] M. Los, K. Khazaie, K. Schulze Osthoff, P.A. Baeuerle, V. Schirrmacher and K. Chlichlia: "Human T cell leukemia virus-I (HTLV-I) Tax-mediated apoptosis in activated T cells requires an enhanced intracellular prooxidant state", J. Immunol., Vol. 161, (1998), pp. 3050-3055.

[33] K. Chlichlia, V. Schirrmacher and R. Sandaltzopoulos: "Cancer immunotherapy: Battling tumors with gene vaccines", Curr. Med. Chem. Anti-Inflammatory \& AntiAllergy Agents, Vol. 4, (2005), pp. 353-366.

[34] H. Modjtahedi and C. Dean: "The binding of HB-EGF to tumour cells is blocked by mAbs which act as EGF and TGF alpha antagonists", Biochem. Biophys. Res. Commun., Vol. 207, (1995), pp. 389-397.

[35] F. Ciardiello, R. Bianco, V. Damiano, S. De Lorenzo, S. Pepe, S. De Placido, Z. Fan, J. Mendelsohn, A.R. Bianco and G. Tortora: "Antitumor activity of sequential treatment with topotecan and anti-epidermal growth factor receptor monoclonal antibody C225", Clin. Cancer Res., Vol. 5, (1999), pp. 909-916.

[36] F. Caponigro, R. Formato, M. Caraglia, N. Normanno and R.V. Iaffaioli: "Monoclonal antibodies targeting epidermal growth factor receptor and vascular endothelial growth factor with a focus on head and neck tumors", Curr. Opin. Oncol., Vol. 17, (2005), pp. 212-217.

[37] R. Li, D.S. Xiong, X.F. Shao, J. Liu, Y.F. Xu, Y.S. Xu, H.Z. Liu, Z.P. Zhu and C.Z. Yang: "Production of neutralizing monoclonal antibody against human vascular endothelial growth factor receptor II", Acta Pharmacol. Sin., Vol. 25, (2004), pp. 1292-1298.

[38] E. Surmacz: "Growth factor receptors as therapeutic targets: strategies to inhibit the insulin-like growth factor I receptor", Oncogene, Vol. 22, (2003), pp. 6589-6597.

[39] M. Stern and R. Herrmann: "Overview of monoclonal antibodies in cancer therapy: present and promise", Crit. Rev. Oncol. Hematol., Vol. 54, (2005), pp. 11-29.

[40] J. Schlessinger: "New roles for Src kinases in control of cell survival and angiogenesis", Cell, Vol. 100, (2000), pp. 293-296.

[41] P. Cairns, K. Okami, S. Halachmi, N. Halachmi, M. Esteller, J.G. Herman, J. Jen, W.B. Isaacs, G.S. Bova and D. Sidransky: "Frequent inactivation of PTEN/MMAC1 in primary prostate cancer", Cancer Res., Vol. 57, (1997), pp. 4997-5000.

[42] M.E. McMenamin, P. Soung, S. Perera, I. Kaplan, M. Loda and W.R. Sellers: "Loss 
of PTEN expression in paraffin-embedded primary prostate cancer correlates with high Gleason score and advanced stage", Cancer Res., Vol. 59, (1999), pp. 4291-4296.

[43] G.D. Lewis, I. Figari, B. Fendly, W.L. Wong, P. Carter, C. Gorman and H.M. Shepard: "Differential responses of human tumor cell lines to anti-p185HER2 monoclonal antibodies", Cancer Immunol. Immunother., Vol. 37, (1993), pp. 255-263.

[44] P. Carter, L. Presta, C.M. Gorman, J.B. Ridgway, D. Henner, W.L. Wong, A.M. Rowland, C. Kotts, M.E. Carver and H.M. Shepard: "Humanization of an antip185HER2 antibody for human cancer therapy", Proc. Natl. Acad. Sci. U.S.A., Vol. 89, (1992), pp. 4285-4289.

[45] R. Nahta, G.N. Hortobagyi and F.J. Esteva: "Growth factor receptors in breast cancer: potential for therapeutic intervention", Oncologist, Vol. 8, (2003), pp. 5-17.

[46] B.A. Burtness, Y. Li, W. Flood, B.I. Mattar and A. Forastiere: "Phase III randomized trial of cisplatin plus placebo versus cisplatin $+\mathrm{C} 225$, a monoclonal antibody directed to the epidermal growth factor-receptor: An Eastern Cooperative Oncology Group trial", Clin. Cancer Res., Vol. 9, (2003), p. 6088S.

[47] D. Cunningham, Y. Humblet, S. Siena, D. Khayat, H. Bleiberg, A. Santoro, D. Bets, M. Mueser, A. Harstrick, C. Verslype, I. Chau and E. Van Cutsem: "Cetuximab monotherapy and cetuximab plus irinotecan in irinotecan-refractory metastatic colorectal cancer", N. Engl. J. Med., Vol. 351, (2004), pp. 337-345.

[48] H.Q. Xiong, A. Rosenberg, A. LoBuglio, W. Schmidt, R.A. Wolff, J. Deutsch, M. Needle and J.L. Abbruzzese: "Cetuximab, a monoclonal antibody targeting the epidermal growth factor receptor, in combination with gemcitabine for advanced pancreatic cancer: a multicenter phase II Trial", J. Clin. Oncol., Vol. 22, (2004), pp. 2610-2616.

[49] P.M. Harari: "Promising new advances in head and neck radiotherapy", Ann, Oncol., Vol. 16, Suppl. 6, (2005), pp. vi13-vi9.

[50] E.K. Rowinsky, G.H. Schwartz, J.A. Gollob, J.A. Thompson, N.J. Vogelzang, R. Figlin, R. Bukowski, N. Haas, P. Lockbaum, Y.P. Li, R. Arends, K.A. Foon, G. Schwab and J. Dutcher: "Safety, pharmacokinetics, and activity of ABX-EGF, a fully human anti-epidermal growth factor receptor monoclonal antibody in patients with metastatic renal cell cancer", J. Clin. Oncol., Vol. 22, (2004), pp. 3003-3015 ^

[51] P. Matar, F. Rojo, R. Cassia, G. Moreno-Bueno, S. Di Cosimo, J. Tabernero, M. Guzman, S. Rodriguez, J. Arribas, J. Palacios and J. Baselga: "Combined epidermal growth factor receptor targeting with the tyrosine kinase inhibitor gefitinib (ZD1839) and the monoclonal antibody cetuximab (IMC-C225): superiority over single-agent receptor targeting", Clin. Cancer Res., Vol. 10, (2004), pp. 6487-6501.

[52] S. Huang, E.A. Armstrong, S. Benavente, P. Chinnaiyan and P.M. Harari: "Dualagent molecular targeting of the epidermal growth factor receptor (EGFR): combining anti-EGFR antibody with tyrosine kinase inhibitor", Cancer Res., Vol. 64, (2004), pp. 5355-5362.

[53 H. Hurwitz, L. Fehrenbacher, W. Novotny, T. Cartwright, J. Hainsworth, W. Heim, J. Berlin, A. Baron, S. Griffing, E. Holmgren, N. Ferrara, G. Fyfe, B. Rogers, R. 
Ross and F. Kabbinavar: "Bevacizumab plus irinotecan, fluorouracil, and leucovorin for metastatic colorectal cancer", N. Engl. J. Med., Vol. 350, (2004), pp. 2335-2342. [54 A.M. Mauer, E.E.W. Cohen, S.J. Wong, M. Kozloff, J. Winegarden, D.M. Gustin and E.E. Vokes: "Phase I study of epidermal growth factor receptor (EGFR) inhibitor, erlotinib, and vascular endothelial growth factor monoclonal antibody, bevacizumab, in recurrent and/ or metastatic squamous cell carcinoma of the head and neck (SCCHN)", Proc. Am. Soc. Clin. Oncol., Vol. 23, (2004), pp. 497.

[55 R.S. Herbst, D.H. Johnson, E. Mininberg, D.P. Carbone, T. Henderson, E.S. Kim, G. Blumenschein Jr., J.J. Lee, D.D. Liu, M.T. Truong, W.K. Hong, H. Tran, A. Tsao, D. Xie, D.A. Ramies, R. Mass, S. Seshagiri, D.A. Eberhard, S.K. Kelley and A. Sandler: "Phase I/II trial evaluating the anti-vascular endothelial growth factor monoclonal antibody bevacizumab in combination with the HER-1/epidermal growth factor receptor tyrosine kinase inhibitor erlotinib for patients with recurrent non-small-cell lung cancer", J. Clin. Oncol., Vol. 23, (2005), pp. 2544-2555.

[56 $\rceil_{\bigwedge}$ T.J. Kroczak, J. Baran, J.S. Pryjma, M. Siedlar, I. Rashedi, E. Hernandez, E. Alberti, S. Maddika and M. Los: "The emerging importance of DNA mapping and other comprehensive screening techniques as tools to identify new drug targets and as a mean of (cancer) therapy personalization", Expert Opin. Ther. Targets, Vol. 10, (2006), pp. 289-302.

[57 T.A. Waldmann: "Immunotherapy: past, present and future", Nat. Med., Vol. 9, (2003), pp. 269-277.

[58 $\rceil_{\bigwedge}$ M. Bruggemann, G.T. Williams, C.I. Bindon, M.R. Clark, M.R. Walker, R. Jefferis, H. Waldmann and M.S. Neuberger: "Comparison of the effector functions of human immunoglobulins using a matched set of chimeric antibodies", J. Exp. Med., Vol. 166, (1987), pp. 1351-1361.

[59] V. Ghetie and E.S. Ward: "Multiple roles for the major histocompatibility complex class I- related receptor FcRn", Annu. Rev. Immunol., Vol. 18, (2000), pp. 739-766.

[60 6 R.A. Clynes, T.L. Towers, L.G. Presta and J.V. Ravetch: "Inhibitory Fc receptors modulate in vivo cytoxicity against tumor targets", Nat. Med., Vol. 6, (2000), pp. 443-446.

[61 $\rceil_{\curlywedge}$ L.M. Weiner and G.P. Adams: "New approaches to antibody therapy", Oncogene, Vol. 19, (2000), pp. 6144-6151.

[62] U. Graeven, B. Kremer, T. Sudhoff, B. Killing, F. Rojo, D. Weber, J. Tillner, C. Unal and W. Schmiegel: "Phase I study of the humanised anti-EGFR monoclonal antibody matuzumab (EMD 72000) combined with gemeitabine in advanced pancreatic eancer", Br. J. Cancer, DOI:10.1038/sj.bjc.6603083. 